\title{
Intensifikasi Lahan Tegalan untuk Meningkatkan Penghasilan Warga Masyarakat Model Daerah Aliran Sungai (DAS) Mikro Cangkringan
}

\author{
Ambar Kusumandari", Supriyandono, Hatma Suryatmojo \\ Program Studi Kehutanan, Fakultas Kehutanan, Universitas Gadjah Mada, Depok, Sleman, D.I. Yogyakarta, \\ Indonesia
}

\section{Submisi: 16 Mei 2020 ; Revisi: 28 Juni 2020; Penerimaan: 29 Juni 2020}

Kata Kunci:

Sengon

Pemberdayaan

Demplot

Agroforestri

MDM

Keywords: Agroforestry Demplot Empowerment Falcatarea Small catchment model.
Abstrak Kerusakan lingkungan di Indonesia sebagai akibat terjadinya bencana banjir, tanah longsor, dan kekeringan semakin meningkat. Berbagai upaya perbaikan kondisi daerah aliran sungai (DAS) sudah dilakukan untuk mewujudkan keseimbangan lingkungan dan tata air DAS serta memberikan manfaat sosial ekonomi yang nyata bagi masyarakat. Kegiatan penelitian dalam pengabdian masyarakat ini bertujuan untuk meningkatkan pengetahuan, pemahaman, dan kesadaran masyarakat terhadap kondisi lingkungan dan upaya pelestariannya; meningkatkan produktivitas lahan melalui pola agroforestri; dan meningkatkan pendapatan masyarakat model DAS mikor (MDM) Cangkringan. Metode yang digunakan adalah melalui pembangunan demontration plot (demplot) partisipatif. Masyarakat terlibat secara aktif sejak dari perencanaan sampai dengan pelaksanaan pembangunan demplot intensifikasi pada lahan tegalan oleh Kelompok Tani Maju Makmur. Melalui sosialisasi kegiatan diperoleh peningkatan pengetahuan, pemahaman, dan kesadaran masyarakat terhadap kondisi lingkungan dan upaya pelestariannya. Dalam perencanaan partisipatif, dipilih tanaman sengon karena memberikan keuntungan ganda, yaitu secara ekologi dan ekonomi. Peningkatan produktivitas lahan pekarangan dilakukan dengan metode yang ramah lingkungan dalam bentuk intensifikasi pekarangan melalui pola agroforestri. Pengembangan agroforestri dilakukan dengan membuat plot percontohan (demplot) oleh Kelompok Tani Maju Makmur. Selanjutnya, pengembangan dapat memberikan hasil berupa berbagai jenis tanaman yang dibudidayakan oleh petani dan dapat dipanen secara berkelanjutan.

Abstract Environmental degradation in Indonesia is increasing as a result of the increasing number of disasters such as floods, landslides and drought. A lot of efforts was created to maintain the equilibrium environment and water regulation of the catchment in order to achieve the better social economic condition of the society. The research in this community service program aims to increase the community's knowledge, understanding and awareness on the environmental condition and conservation; increase land productivity through agroforestry pattern; and increase the income of the community through MDM model in Cangkringan. This program is conducted using participatory demonstration plot. In this case, the community have active roles from the early planning until the implementation in the form of building the intensification demonstration plot on the field by the Maju Makmur farmers group. The socialization resulted in the increase of knowledge, understanding, and awareness of environmental condition and conservation. During the participatory planning, sengon (Falcataria molluccana) was chosen to be planted due to its ecological and economically advantages. The process of increasing the

ISSN 2460-9447 (print), ISSN 2541-5883 (online)

${ }^{*}$ Corresponding author: Pande Ayu Naya Kasih Permatananda

Departemen Farmakologi dan Farmasi, Fakultas Kedokteran dan IImu Kesehatan, Jl. Teropong no 24 Denpasar, Indonesia 80234

Email:nayakasih@gmail.com 
land productivity was done in ecologically friendly way in the form of intensifying the land by developing agroforestry pattern. The development of agroforestry pattern was done by establishing demonstration plot by Maju Makmur farmers group. Furthermore, the agroforestry development in Kopeng sub village may resulted in several species which can be planted by the farmers and are able to be harvested simultaneously.

\section{PENDAHULUAN}

Kerusakan lingkungan di Indonesia telah menjadi keprihatinan banyak pihak. Hal ini ditandai dengan bertambahnya bencana alam seperti bencana banjir, tanah longsor, dan kekeringan. Bahkan dalam skala internasional degradasi lahan masih menjadi masalah utama (Arif, 2020). Rendahnya daya dukung daerah aliran sungai (DAS) sebagai suatu ekosistem diduga menjadi salah satu penyebab utama terjadinya bencana alam yang terkait dengan air (water related disaster). Eksploitasi sumber daya alam berupa penambangan dan penebangan hutan semakin memperparah kondisi DAS di Indonesia. Akibatnya, fungsi DAS sebagai penyimpan air mengalami degradasi (Suprayogi et al., 2014). Berbagai upaya perbaikan kondisi DAS sudah mulai dilakukan untuk mewujudkan keseimbangan lingkungan dan tata air DAS serta memberikan manfaat sosial ekonomi yang nyata bagi masyarakat.

Sehubungan dengan hal tersebut, maka Balai Pengelolaan Daerah Aliran Sungai (BPDAS) bersamasama dengan pihak terkait termasuk masyarakat perlu mengembangkan area model pengelolaan DAS terpadu dalam luasan relatif kecil (DAS mikro) yang mencakup kegiatan dengan prinsip pengelolaan sumber daya alam lestari dari aspek biogeofisik, sosial ekonomi, dan kelembagaan (P.15/V-SET/2009). Kajian DAS mikro penting dilakukan untuk menerapkan desain projek dan mengambil keputusan dalam mengatasi kendala dan permasalahan lokal atau pada skala kecil, yaitu DAS mikro. Melalui model DAS mikro (MDM), maka berbagai komponen fisik dan biotik yang terkait dengan fungsi DAS dapat dimonitor dan dikendalikan (Smyle et al., 2014).

Luas MDM Cangkringan yaitu 1.354,01 ha sehingga termasuk ke dalam kategori DAS sangat kecil. MDM Cangkringan memiliki bentuk DAS yang memanjang. Hal ini dapat dilihat dari nilai circularity ratio (Rc), yaitu sebesar 0,207. Bentuk DAS ditentukan dari Rc, yaitu perbandingan antara luas DAS dengan luas lingkaran yang mempunyai perimeter sama dengan DAS, bila Rc $<0,5$ berarti bentuk DAS memanjang. Bentuk DAS yang memanjang memiliki time of peak (waktu puncak) banjir yang lambat, artinya jika di bagian hulu terjadi hujan, maka banjir tidak cepat sampai ke hilir. MDM Cangkringan memiliki kemiringan dominan $2 \%-8 \%$ yang menunjukkan tingkat potensi erosi yang tidak besar. Lynsley (1949) menyatakan bahwa jika nilai kepadatan aliran (Dr) lebih kecil dari $1 \mathrm{mile} / \mathrm{mile}^{2}\left(0,62 \mathrm{~km} / \mathrm{km}^{2}\right)$, DAS akan mengalami penggenangan, sedangkan jika nilai kepadatan aliran lebih besar dari 5 mile/mile ${ }^{2}(3,10$ $\mathrm{km} / \mathrm{km}^{2}$ ), DAS sering mengalami kekeringan. Dengan demikian, kondisi kepadatan drainase secara umum di DAS Cangkringan mengalami kekeringan jika dilihat dari nilai kepadatan alirannya yang sebesar 3,81. Jika dilihat dari nilai gradien sungai MDM Cangkringan yang sebesar 0,07, maka potensi erosi permukaan rendah. Akibatnya, debit aliran sungai menjadi rendah dengan kandungan sedimen yang sedikit. Kondisi sungai di MDM Cangkringan dipengaruhi oleh erupsi Gunung Merapi pada tahun 2010 sehingga banyak terjadi penambangan pasir di sungai bagian hulu. Penutupan lahan di MDM Cangkringan terdiri dari 7 tipe yang didominasi oleh kebun $(39,97 \%)$ (Tabel 1). Table 1. Tipe dan luas penutupan lahan di MDM Cangkringan

\begin{tabular}{llll}
\hline No & $\begin{array}{l}\text { Penutupan } \\
\text { lahan }\end{array}$ & Luas (ha) & $\begin{array}{l}\text { Persentase } \\
(\%)\end{array}$ \\
\hline 1 & Belukar/semak & 46.698 & 3,45 \\
2 & Hutan & 0.016 & 0,00 \\
3 & Kebun & 541.154 & 39,97 \\
4 & Pemukiman & 170.324 & 12,58 \\
5 & Rumput & 11.282 & 0,83 \\
6 & Sawah Irigasi & 382.582 & 28,26 \\
7 & Tegalan & 201.956 & 14,92 \\
\hline Jumlah & 1354.012 & 100 \\
\hline Sumber: & Peta rupa bumi Indonesia (RBI) tahun 2013
\end{tabular}

Lahan tegalan yang ada belum dimanfaatkan secara optimal. Sehubungan dengan hal tersebut maka perlu ditingkatkan pemanfaatannya melalui kegiatan intensifikasi lahan tegalan. Roadmap penelitian dalam pengabdian dimulai pada tahun 2016 dimana telah dilakukan penyusunan MDM Cangkringan (Kusumandari dan Suryatmojo, 2016). Selanjutnya, pada tahun berikutnya (2017) dilakukan intensifikasi lahan tegalan. Kegiatan ini ditindaklanjuti dengan pengembangan model kebun di MDM Cangkringan pada tahun 2018 dan dilakukan analisis sumber daya air (2019) dan pengembangan potensi wisata (2020).

Pembangunan demontration plot (demplot) intensifikasi pekarangan melalui pola agroforestri untuk mendukung terbentuknya dusun wisata transit merupakan kegiatan yang membutuhkan peran dan 
dukungan dari berbagai pihak. Para pihak yang dimaksud mencakup masyarakat, Fakultas Kehutanan Universitas Gadjah Mada (UGM), dan instansi/lembaga pemerintahan lainnya termasuk Dinas Kehutanan Provinsi Daerah Istimewa Yogyakarta (DIY), Dinas Kehutanan Kabupaten Sleman, dan Dinas Pariwisata Kabupaten Sleman. Tahapan kegiatan pembangunan demplot dilakukan secara partisipatif dan melibatkan pihak-pihak tersebut.

Bagi masyarakat sekitar, usaha intensifikasi pekarangan melalui pola agroforestri diharapkan mampu memperbaiki kondisi lingkungan. Di sisi lain, penanaman pohon di pekarangan juga diharapkan dapat meningkatkan keindahan kawasan sehingga dapat mendukung upaya pengembangan dusun wisata. Bagi Fakultas Kehutanan UGM, kegiatan ini bertujuan untuk meningkatkan peran akademisi dalam diseminasi ilmu pengetahuan dan teknologi yang diharapkan mampu memberikan manfaat bagi masyarakat. Pemerintah kabupaten dan provinsi mempunyai kepentingan dalam usaha rehabilitasi lahan kritis sesuai amanat Peraturan Daerah Provinsi DIY Nomor 2 tahun 2010 tentang Rencana Tata Ruang Wilayah Provinsi (RTRWP).

Tujuan kegiatan penelitian dalam pengabdian ini adalah untuk meningkatkan pengetahuan, pemahaman, dan kesadaran masyarakat terhadap kondisi lingkungan dan upaya pelestariannya, meningkatkan produktivitas lahan di lahan pekarangan dengan metode yang ramah lingkungan dalam bentuk intensifikasi pekarangan melalui pola agroforestri, dan meningkatkan pendapatan masyarakat MDM Cangkringan.

\section{METODE PELAKSANAAN}

Kegiatan penelitian dalam pengabdian kepada masyarakat ini dilaksanakan pada Maret sampai dengan September 2017 dengan bantuan pendanaan dari DPP Fakultas Kehutanan UGM. Kegiatan ini mendapatkan bantuan berupa bibit sengon dari BPDAS Serayu Opak Progo. Masyarakat yang aktif mengikuti kegiatan ini adalah para petani yang tergabung dalam Kelompok Tani Maju Makmur di Dusun Kopeng, Desa Kepuharjo, Kecamatan Cangkringan, Sleman.

Metode yang diterapkan dalam setiap tahapan pelaksanaan kegiatan penelitian dalam pengabdian kepada masyarakat ini diuraikan sebagai berikut.

\subsection{Survey, sosialisasi program, dan penyuluhan}

Survey lokasi kegiatan bertujuan untuk mengetahui gambaran umum kondisi lokasi pelaksanaan kegiatan, meliputi kondisi fisik, biologis, sosial ekonomi, budaya, dan kelembagaan serta untuk mengetahui potensi wilayah dan permasalahan lingkungan yang dihadapi oleh masyarakat. Kegiatan survei ini dilakukan dengan melaksanakan kunjungan langsung, pengumpulan data sekunder, dan berdiskusi dengan perangkat desa, kelompok masyarakat di MDM Cangkringan, serta instansi terkait. Sosialisasi dilakukan untuk menyampaikan maksud dan tujuan dari kegiatan intensifikasi pekarangan melalui pola agroforestri.

Dengan adanya sosialisasi ini masyarakat mengerti dan memahami pentingnya usaha penanaman pohon buah-buahan melalui pola agroforestri di MDM Cangkringan. Dengan timbulnya kesadaran tersebut, kepedulian masyarakat untuk menjaga dan melindungi kawasan juga meningkat. Dalam sosialisasi tersebut sekaligus dilakukan penyuluhan kepada anggota kelompok tani. Transfer ilmu dan pengetahuan dilakukan dengan presentasi materi oleh tim penelitian. Selanjutnya dilakukan diskusi, tanya jawab, serta pengisian kuisioner oleh seluruh petani yang hadir dalam pertemuan tersebut.

\subsection{Perencanaan demplot partisipatif}

Perencanaan penanaman dilaksanakan secara partisipatif, yaitu melibatkan masyarakat dalam menyusun perencanaan dan pelaksanaannya. Demplot dapat dijadikan media edukasi dan pemberdayaan masyarakat secara luas. Perencanaan pembuatan demplot agroforestri dilakukan melalui diskusi terarah yang dihadiri oleh kelompok masyarakat, aparat pemerintah desa, dan instansi terkait. Demplot yang dibuat merupakan demplot agroforestri dengan menambahkan tanaman sengon di sela-sela tanaman yang sudah ada.

\subsection{Pembangunan demplot}

Pembangunan demplot dilakukan melalui beberapa tahap.

\subsubsection{Penentuan lokasi demplot}

Demplot dibangun pada lahan tegalan dengan area yang mengelompok (blok) dalam bentuk tanaman pagar dan tanaman pengkaya. Tujuan pembuatan demplot tersebut adalah memberikan contoh pola pertanaman yang ramah lingkungan dan mendukung intensifikasi pekarangan melalui pola agroforestri berupa penanaman pohon sengon.

\subsubsection{Pengukuran dan pemancangan batas demplot}

Pengukuran dan pemancangan batas demplot perlu dilakukan agar demplot yang dibangun sesuai dengan pola tanam dan jarak tanam serta teknik intensifikasi pekarangan yang telah ditentukan.

\subsubsection{Penanaman bibit di lahan}

Penanaman dilakukan dalam beberapa tahap.

a. Persiapan lahan

Persiapan lahan dilakukan dengan pembersihan lahan dari tumbuhan bawah, semak dan perdu. Hal ini perlu dilakukan agar tanaman dapat tumbuh dengan baik. 


\section{b. Penentuan dan pengukuran jarak tanam}

Penentuan jarak tanam dilakukan agar tanaman yang ditanam memperoleh ruang tumbuh yang cukup, sehingga tanaman dapat tumbuh secara optimal. Penentuan jarak tanam disesuaikan dengan jenis tanaman.

\section{c. Pembuatan lubang tanam}

Pembuatan lubang tanam merupakan salah satu komponen kegiatan yang sangat penting. Bentuk, ukuran, dan kedalaman lubang tanam harus disesuaikan dengan dimensi media bibit serta jenis tanaman yang akan ditanam

\section{d. Pemberian pupuk}

Pemberian pupuk dilakukan dengan tujuan agar bibit tanaman mendapat asupan unsur hara yang cukup. Pemberian pupuk harus diperkirakan agar tidak terlalu sedikit atau terlalu banyak. Pemberian pupuk yang berlebih akan menghambat pertumbuhan karena pupuk tidak lagi berfungsi sebagai asupan hara melainkan berubah menjadi racun. Pada prinsipnya, pemberian pupuk dapat dilakukan sebelum dan sesudah penanaman. Pemberian pupuk pada lubang tanam sebelum penananam bertujuan agar gas dan zat beracun lainnya yang terkandung dalam pupuk dapat diuraikan terlebih dahulu sehingga pada saat ditanam pupuk sudah dalam bentuk yang siap dimanfaatkan oleh tanaman.

\section{e. Penanaman}

Penanaman bibit sengon dilakukan setelah lubang tanam siap dan telah diberi pupuk. Penanaman perlu memperhatikan prinsip keamanan dan kesehatan bibit. Akar tidak boleh terlipat atau patah karena akan menghambat pertumbuhan akar atau memicu munculnya penyakit. Selain itu, kontener atau wadah bibit harus dilepas untuk memberikan ruang yang optimal bagi pertumbuhan akar.

\section{HASIL DAN PEMBAHASAN}

Penerapan agroforestri di lahan tegalan bertujuan untuk mengoptimalkan lahan sehingga mampu memberikan keuntungan bagi masyarakat baik secara ekologi maupun ekonomi. Kegiatan ini membutuhkan peran dan dukungan dari berbagai pihak, baik dari masyarakat, Fakultas Kehutanan UGM dan instansi/lembaga pemerintah lainnya seperti Dinas Kehutanan Provinsi DIY, Balai Pengelolaan DAS dan Hutan Lindung (HL) Serayu Opak Progo, dan Dinas Kehutanan Kabupaten Sleman. Kegiatan ini dilakukan secara partisipasif dan melibatkan pihak-pihak tersebut. Bagi masyarakat sekitar, usaha intensifikasi pekarangan melalui pola agroforestri diharapkan mampu meningkatkan kepedulian masyarakat Dusun
Kopeng terhadap fungsi ekologis sekaligus fungsi ekonomis. Bagi Fakultas Kehutanan UGM, kegiatan ini bertujuan untuk meningkatkan peran akademisi dalam diseminasi ilmu pengetahuan dan teknologi yang bermanfaat bagi masyarakat.

\subsection{Sosialisasi program}

Kegiatan penelitian dalam pengabdian kepada masyarakat ini diawali dengan survei lokasi dan sosialisasi program yang bertujuan untuk mengetahui gambaran umum lokasi pelaksanaan kegiatan, meliputi aspek fisik, biologis, sosial ekonomi, budaya, dan kelembagaan serta untuk mengetahui potensi wilayah dan permasalahan lingkungan yang dihadapi oleh masyarakat. Kegiatan survei dilakukan dengan kunjungan langsung, pengumpulan data sekunder, dan diskusi dengan perangkat desa terkait rencana kegiatan.

Sosialisasi dilakukan untuk menyampaikan maksud dan tujuan dari kegiatan pengoptimalan lahan pekarangan dengan sistem agroforestri di MDM Cangkringan pada khususnya dan masyarakat luas pada umumnya. Pelaksanaan kegiatan sosialisasi dilakukan pada malam Minggu Wage yang bertepatan dengan pertemuan rutin warga. Sasaran peserta sosialisasi adalah Kelompok Tani Maju Makmur, Dusun Kopeng, Desa Kepuharjo.

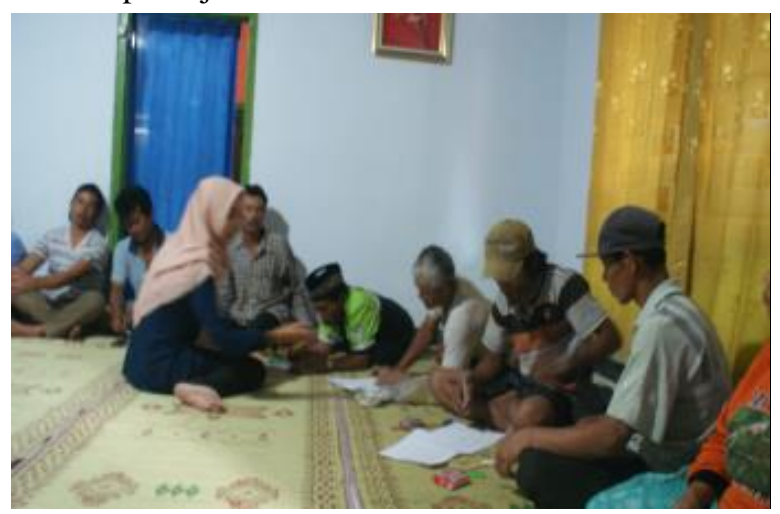

Gambar 1. Sosialisasi mengenai intensifikasi lahan tegalan

\subsubsection{Profil responden}

Profil responden berdasarkan jenis kelamin, kelas umur, tingkat pendidikan, dan jenis pekerjaan dapat dilihat pada Gambar 2, 3 dan 4

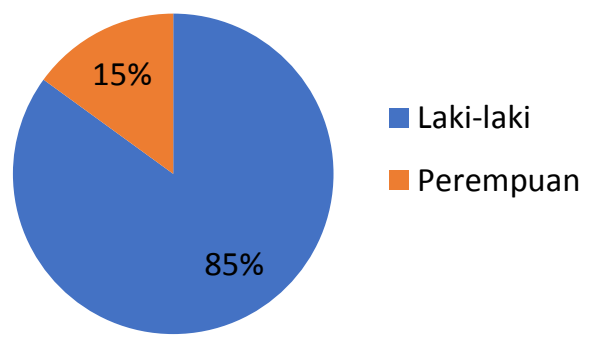




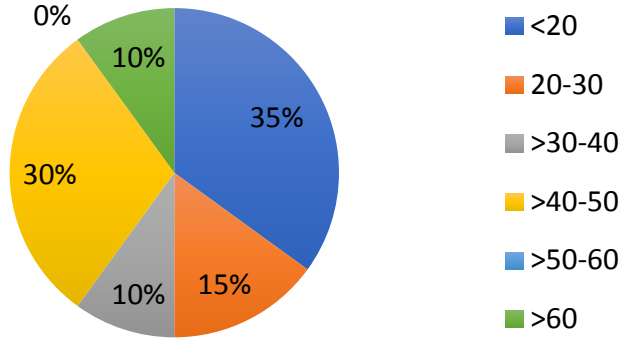

Gambar 2. Profil responden berdasarkan jenis kelamin dan kelas umur

Jenis kelamin responden yang mengikuti kegiatan intensifikasi lahan tegalan mayoritas adalah laki-laki. Laki-laki lebih sering mengolah lahan seperti mencangkul, mencari pakan ternak, menanam tanaman, dan menghilangkan gulma daripada perempuan yang lebih sering mengurus kegiatan rumah.

Mayoritas peserta berusia 40-60 tahun. Hal tersebut terjadi karena orang berusia 30-40 tahun lebih memilih pekerjaan lain dengan penghasilan yang lebih baik seperti pekerja tambang atau wiraswasta, sedangkan penduduk yang berusia usia di bawah 30 tahun sebagian besar sedang menempuh pendidikan atau bekerja di kota lain.

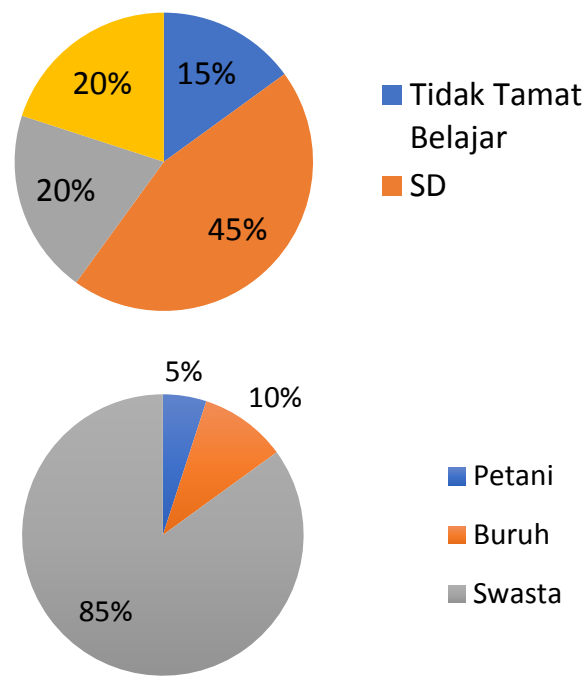

Gambar 3. Profil responden berdasarkan tingkat pendidikan dan jenis pekerjaan

Penduduk yang tetap tinggal di desa biasanya memiliki tingkat pendidikan yang rendah. Tingkat pendidikan yang rendah sangat berpengaruh terhadap sedikitnya peluang kerja. Masyarakat yang tetap tinggal di desa mayoritas lebih memilih mengolah lahan dan fokus pada bercocok tanam atau memanfaatkan sumber daya alam yang ada di sekitarnya.

Sebagian besar mata pencaharian masyarakat Dusun Kopeng adalah bertani, meskipun masih terdapat masyarakat yang bekerja sebagai penambang bahan galian C dan jenis pekerjaan lain. Dusun Kopeng berada tidak jauh dari puncak Gunung Merapi yang menyebabkan kondisi lahan di daerah tersebut masih mengandung material erupsi yang memengaruhi kualitas tanah. Erupsi Gunung Merapi yang terjadi secara periodik menyebabkan banyaknya material pasir yang membuka peluang bagi masyarakat untuk melakukan kegiatan pertambangan. Kegiatan tersebut berdampak pada menurunnya daya dukung lingkungan sehingga intensifikasi lahan tegalan dianggap sebagai salah satu alternatif kegiatan pengelolaan sumber daya alam bagi masyarakat Dusun Kopeng.

\subsubsection{Kepemilikan lahan dan penggunaan lahan}

Gambaran luas lahan yang dimiliki, kemiringan lahan, pola tanam, dan jenis tanaman yang ditanam dapat dilihat pada Gambar 4 dan 5
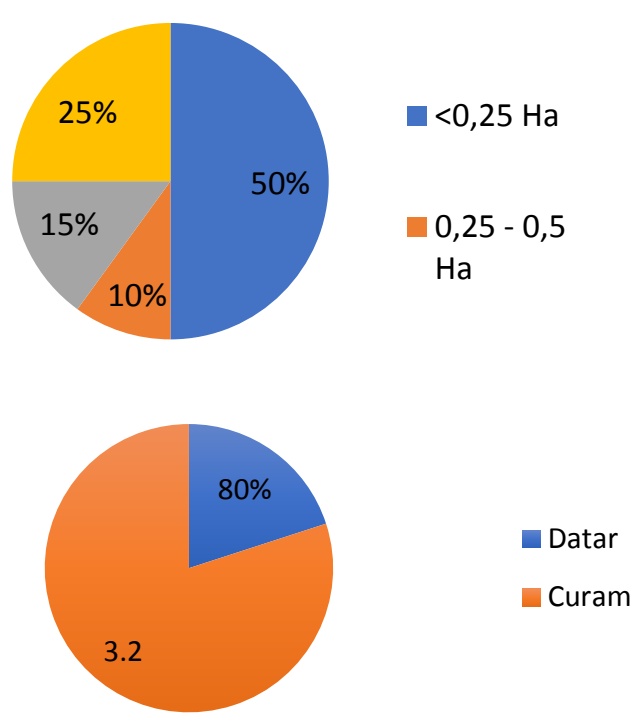

Gambar 4. Karakteristik luas dan kemiringan lahan yang dimiliki responden

Luas lahan tegalan yang dimiliki masyarakat sebagian besar kurang dari 0,25 ha, namun masih terdapat sebagian masyarakat yang memiliki luas lahan $>1$ Ha. Biasanya, kepemilikan lahan di pulau Jawa memang tidak lebih dari 0,25 ha, hal ini berkaitan dengan kepadatan penduduk di Pulau Jawa sehingga kebutuhan lahan untuk pemukiman dan penggunaan lain sangat tinggi. Hal tersebut berdampak pada luasan lahan yang dimiliki untuk bercocok tanam.

Lahan yang digunakan petani untuk bercocok tanam adalah lahan yang memiliki kelerengan datar. Secara prinsip, lereng yang datar akan lebih dipilih petani untuk bercocok tanam dibandingkan lereng yang curam. Lereng yang datar akan memudahkan petani dalam aksesibilitas, lebih hemat biaya dan tenaga dalam pengolahan lahan dan perawatan tanaman, serta mengurangi risiko terjadinya bencana seperti longsor. 

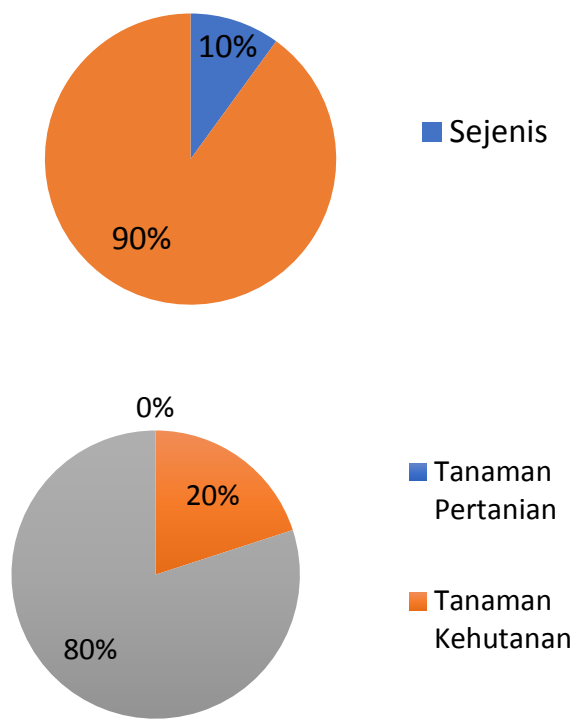

Gambar 5. Pola tanam dan jenis tanaman yang diusahakan responden

Pola tanam yang diusahakan oleh responden adalah pola tanam campuran dimana terdapat banyak jenis tanaman dalam satu lahan. Jenis-jenis yang dipilih adalah jenis yang dianggap memiliki manfaat bagi masyarakat sehingga antara repsonden satu dengan responden lain akan mempunyai pilihan tanaman yang berbeda-beda. Jenis tanaman yang diusahakan sebagian besar adalah tanaman pertanian dan tanaman kehutanan, namun ada pula beberapa responden yang mengisi lahan mereka dengan jenis tanaman kehutanan saja. Apabila masyarakat mengusahakan jenis tanaman pertanian dan kehutanan dalam satu lahan, maka kebutuhan jangka pendek dan jangka panjang dapat terpenuhi. Hal tersebut berbeda jika jenis yang diusahakan adalah jenis tanaman kehutanan saja maka membutuhkan waktu yang cukup lama untuk memanen hasilnya.

\subsubsection{Intensifikasi penggunaan lahan}

Intensifikasi penggunaan lahan digambarkan berdasarkan tingkat pengetahuan tentang agroforestri, intensitas responden mengunjungi lahan, jenis tanaman yang sudah ditanam, intensitas panen, dan hasil yang diperoleh.
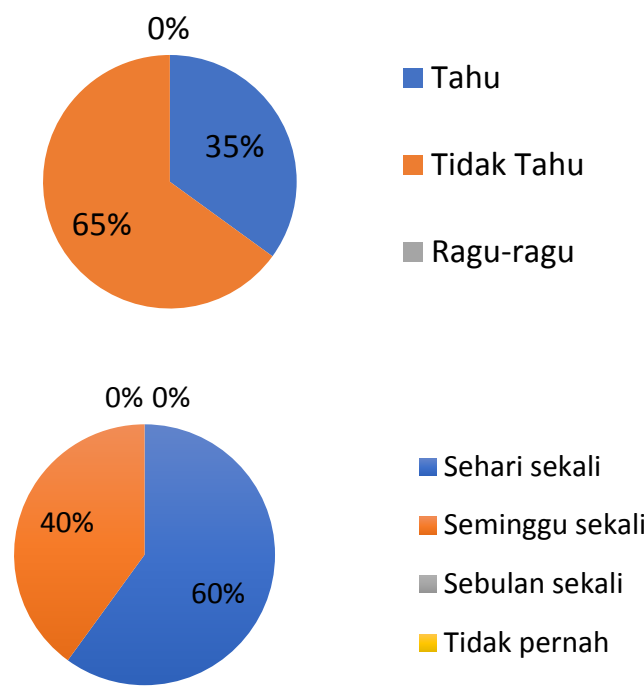

Gambar 6. Pengetahuan tentang agroforestri dan intensitas responden mengunjungi lahan.

Sebagian responden justru tidak mengetahui istilah agroforestri meskipun dalam kenyataannya mereka menggunakan sistem tersebut. Hal ini terjadi karena masyarakat tidak terbiasa dengan istilah-istilah agroforestri atau tumpangsari dalam kehidupan seharihari. Sebagian besar responden mengunjungi lahan sebanyak satu hari sekali untuk mengambil pakan ternak. Selain rumput, daun-daun pohon juga dapat dipakai sebagai pakan ternak. Bagi responden yang mengunjungi lahan satu minggu sekali biasanya mereka mengusahakan tanaman kehutanan sehingga tidak membutuhkan perawatan yang intensif.

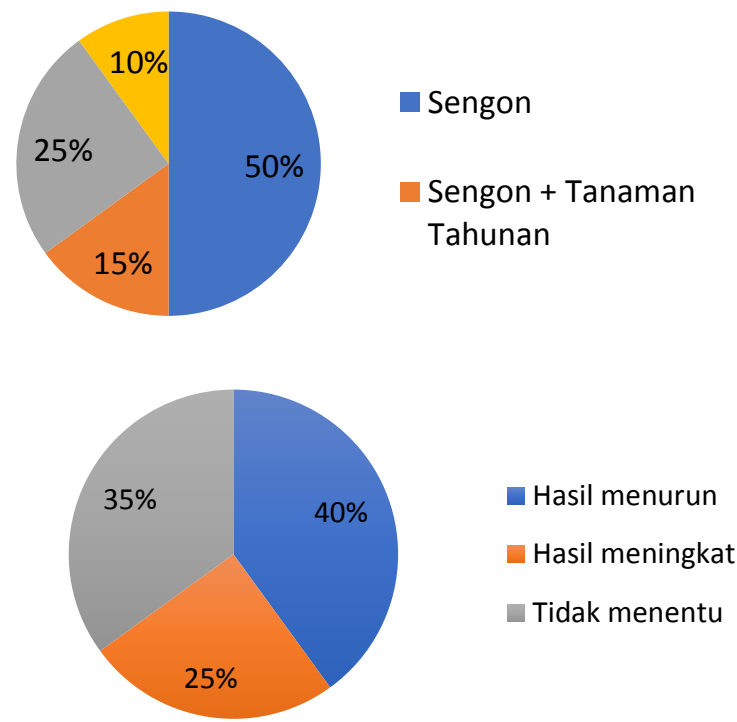

Gambar 7. Jenis tanaman dan hasil dari lahan yang dirasakan oleh responden. 
Jenis tanaman yang sudah ada di lahan responden adalah sengon meskipun ada pula jenis tanaman lain seperti tanaman buah, kopi, cengkeh, dan jenis lain. Hal ini disebabkan oleh pasca-erupsi besar yang terjadi tahun 2010, pemerintah setempat melakukan rehabilitasi lahan dengan menanam jenis sengon di seluruh area terdampak erupsi. Sengon dianggap mudah tumbuh dan memiliki masa panen yang cepat. Selain itu, kebutuhan akan kayu sengon tergolong tinggi (Nugroho dan Salamah, 2015) sehingga masyarakat mengusahakan jenis sengon di lahan mereka.

Empat puluh persen reponden merasakan hasil panen dari lahan yang semakin menurun dan $35 \%$ menyatakan hasil yang diperoleh tidak menentu. Banyaknya sengon yang terkena penyakit karat puru (benjol) dianggap sebagai penyebab menurunnya hasil lahan. Oleh karena itu, perlu adanya tindakan silvikultur terutama pengendalian hama dan penyakit agar hasil yang diperoleh tidak terus mengalami penurunan. Namun demikian, ada pula responden yang merasakan hasil dari lahan yang meningkat. Biasanya, bagi petani yang merasakan peningkatan hasil akan lebih intensif dalam pengelolaan lahan dan perawatan tanaman sehingga kejadian yang tidak diinginkan dapat segera teratasi.
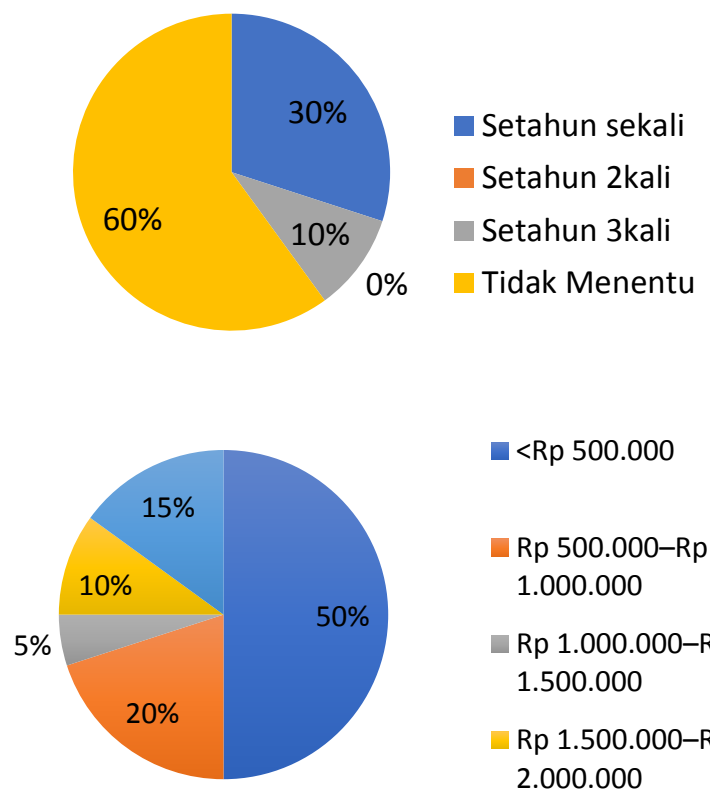

— $<$ Rp 500.000

Rp 500.000-Rp

1.000 .000

Rp 1.000.000-Rp

1.500 .000

Rp 1.500.000-Rp 2.000 .000

Gambar 8. Intensitas panen dan nominal yang diperoleh.

Karena sebagian besar responden menanam sengon atau tanaman kehutanan lain, maka hal tersebut berpengaruh terhadap intensitas panen. Tanaman kehutanan membutuhkan waktu yang relatif lama untuk menghasilkan kayu atau buah. Sebagian responden yang memilih usaha kayu memiliki masa panen yang tidak menentu karena mereka menggunakan sistem tebang butuh, yaitu mereka akan memanen ketika membutuhkan biaya. Sistem tebang butuh ini biasa dilakukan di daerah pedesaan. Adapun responden yang memiliki masa panen setahun sekali atau setahun 3 kali biasanya mengusahakan jenis-jenis tanaman tahunan seperti kopi, cengkeh, atau tanaman pertanian lain.

Mayoritas responden memperoleh uang kurang dari Rp 1.000.000,00 dalam sekali panen. Hal tersebut disebabkan oleh sistem yang digunakan, dalam hal ini volume kayu yang dipanen sedikit atau secukupnya. Sisa tegakan akan dipanen di waktu yang akan datang sebagai tabungan atau investasi.

\subsubsection{Upaya yang dilakukan untuk mengoptimalkan lahan}

Upaya yang dilakukan responden untuk mengurangi kerusakan lingkungan, pengetahuan responden tentang manfaat pohon yang dapat mengurangi kerusakan lingkungan, kesediaan menanam pohon, dan riwayat pernah mengikuti sosialisasi agroforestri disajikan dalam Gambar 9 dan 10.
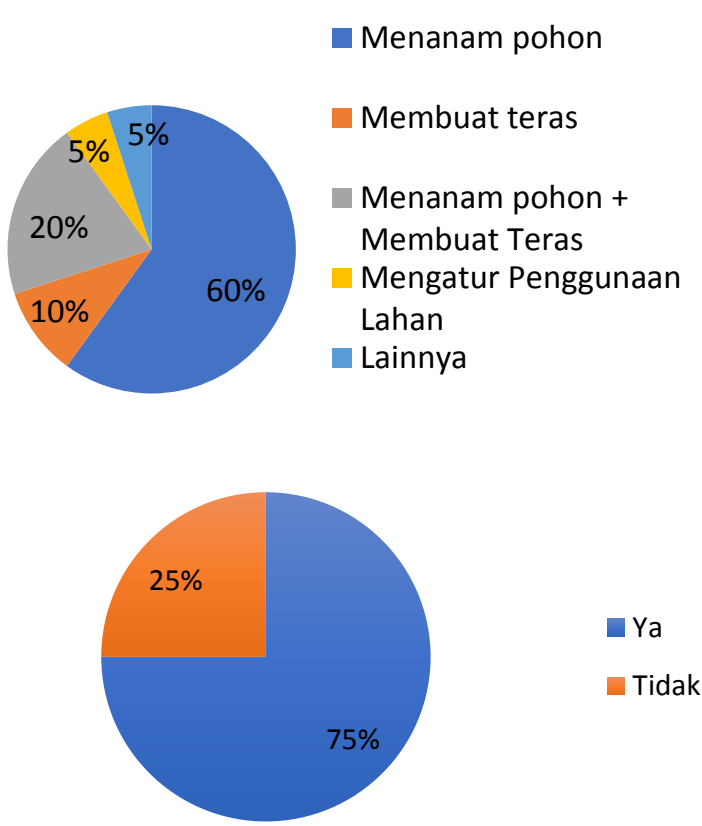

Gambar 9. Upaya yang dilakukan responden untuk mengurangi kerusakan lingkungan dan pengetahuan responden.

Upaya yang dilakukan masyarakat untuk menurangi kerusakan lingkungan adalah menanam pohon dan membuat teras. Responden menganggap pohon memiliki fungsi ekologis yang baik sehingga mampu mengurangi kerusakan lingkungan. Bangunan teknis seperti teras juga digunakan untuk mengurangi kerusakan lahan mengingat ada beberapa responden yang memiliki lahan curam.

Sebanyak $75 \%$ responden mengetahui bahwa pohon dapat mengurangi kerusakan lingkungan melalui sistem perakarannya. Namun, ada juga responden yang tidak mengetahui fungsi pohon untuk mengurangi 
kerusakan lingkungan. Dengan demikian, perlu diadakan pembinaan atau pendampingan lebih lanjut kepada petani Dusun Kopeng.
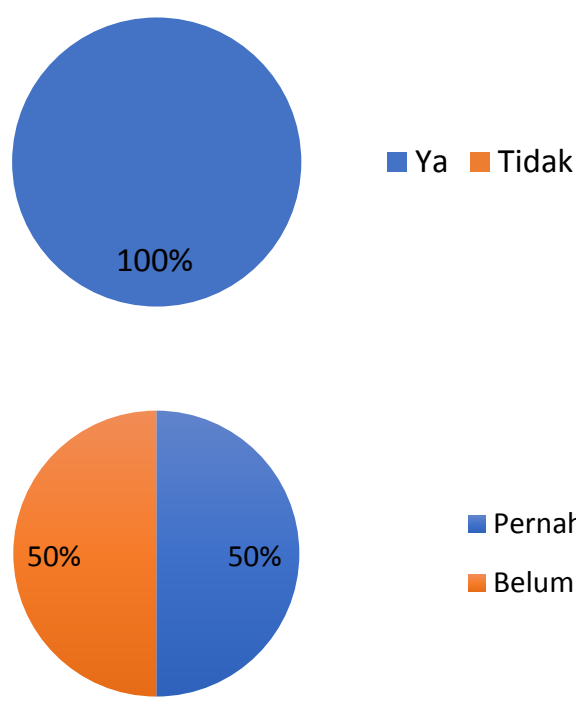

- Pernah

Belum

Gambar 10. Kesediaan responden untuk menanam pohon dan kegiatan sosialisasi

Seluruh responden bersedia untuk menanam pohon di lahan. Mereka menyadari bahwa pohon memiliki fungsi ekologis dan fungsi ekonomis. Pohon dianggap sebagai tabungan atau investasi. Jenis-jenis yang diinginkan responden sebagian besar adalah sengon. Jenis tanaman lain yang diinginkan adalah kakao, cengkeh, pisang, dan yang lainnya. Sengon tetap menjadi primadona karena perawatannya yang mudah dan masa tunggu panen yang relatif singkat serta harga kubikasi kayu sengon yang relatif tinggi dibandingkan dengan jenis kayu lainnya. Selain itu, daun sengon dapat dijadikan sebagai pakan ternak. Menurut responden, peluang pasar untuk kayu sengon sangat bagus. Konsumen kayu sengon untuk bahan mebel relatif banyak sehingga peluang pasar untuk kayu sengon sangat menjanjikan.

Sebanyak 50\% responden belum pernah mengikuti sosialisasi dan $50 \%$ yang lain sudah pernah mengikuti sosialisasi. Sosialisasi tersebut diselenggarakan oleh dinas setempat atau Kelompok Tani Maju Makmur di Dusun Kopeng. Materi sosialisasi yang diberikan berkaitan dengan rehabilitasi lahan. Hal ini dilakukan dengan pertimbangan bahwa sebagian kawasan Dusun Kopeng merupakan kawasan yang terdampak erupsi Gunung Merapi.

\subsection{Perencanaan demplot}

\subsubsection{Perencanaan demplot secara partisipatif}

Dalam tahapan perencanaan pembuatan demplot secara partisipatif ini, disepakati bahwa dalam rangka intensifikasi lahan tegalan akan dibangun percontohan penanaman sengon dengan pembuatan demontration plot (demplot) seluas $\pm 3000 \mathrm{~m}^{2}$ di tanah lungguh. Tanah lungguh adalah tanah milik desa yang digarap oleh perangkat desa setempat. Perencanaan penanaman dilaksanakan secara partisipatif, yaitu dengan melibatkan masyarakat dalam perencanaan dan pelaksanaan. Demplot tersebut diharapkan dapat dijadikan media edukasi dan pemberdayaan masyarakat secara luas. Perencanaan demplot agroforestri dilaksanakan melalui diskusi terarah yang dihadiri oleh kelompok masyarakat, aparat pemerintah desa, dan instansi terkait.

\subsubsection{Deskripsi Sengon}

Sengon (Falcataria moluccana) (Gambar 11) merupakan salah satu jenis tanaman yang pertumbuhannya cepat, masa panennya pendek, bersifat multi fungsi, dan memberikan dampak ganda baik aspek ekologi maupun aspek ekonomi. Pada aspek ekologi, sengon dapat meningkatkan kualitas lingkungan seperti meningkatkan kesuburan tanah dan memperbaiki tata air (Suharti, 2008). Sengon memiliki akar tunggang yang cukup kuat untuk menembus ke dalam tanah. Rambut akar sengon mampu menyerap nitrogen sehingga tanah di sekitar pohon menjadi subur. Kondisi ini sangat menguntungkan bagi pertumbuhan tanaman lain yang ketinggiannya lebih rendah. Keadaan multi strata pada sistem agroforestri ini mampu mengurangi energi kinetik hujan sehingga dapat memperkecil terjadinya erosi dan aliran permukaan (Nair, 1973). Keberadaan pohon diharapkan mampu memperbaiki produktivitas lahan dan dapat memberikan pendapatan untuk perbaikan dalam aspek ekonomi (Sari et al., 2018).

Sengon termasuk jenis yang toleran terhadap tempat tumbuh karena sengon dapat tumbuh mulai dari pantai hingga ketinggian 1600 mdpl. Sengon dapat tumbuh pada tanah regosol, alluvial, dan latosol dengan ph 6-7. Selain itu, sengon juga dapat tumbuh di daerah dengan suhu sekitar $18-27^{\circ} \mathrm{C}$, kelembaban 50\%-75\% dan curah hujan per tahun sekitar 2000-4000 mm (Hardiyatmi,2010). Sengon merupakan salah satu alternatif dan menjadi primadona baru dalam bidang perkayuan karena cepat tumbuh (fast growing species), dapat ditanam di berbagai kondisi tanah, kayunya cenderung lebih lurus, masa tebang lebih pendek, sifat kayunya termasuk kelas awet dan kuat IV-V serta berat jenis 0,24-0,49 dengan rata-rata 0,33. Prospek penggunaan untuk pulp/ kertas termasuk kategori sedang (Kusmawati et al., 2018).

Bagian terpenting yang mempunyai nilai ekonomi pada tanaman sengon adalah kayunya. Seperti halnya kayu jenis lain, kayu sengon mengalami peningkatan harga dari waktu ke waktu. Kayu sengon banyak dibutuhkan pada bidang industri, rumah tangga, 
konstruksi. dan mebel. Banyaknya permintaan dari perusahaan atau masyarakat terhadap kayu sengon menyebabkan harga kayu sengon beranjak naik. Harga per pohon bervariasi tergantung daerah dan besaran pohon yang diperjualbelikan. Semakin besar diameter dan lurus bentuk pohonnya maka akan semakin mahal harganya. Di daerah Sleman, Yogyakarta harga pohon sengon yang telah berumur kira-kira 5 tahun sekitar Rp 1.000.000,00. Pohon sengon dapat mencapai tinggi sekitar 30-45 meter dengan diameter batang sekitar 70$80 \mathrm{~cm}$. Kayu sengon merupakan bahan baku yang mudah dibentuk menjadi berbagai macam kebutuhan, mudah dipaku, mudah kering, tidak gampang pecah, harganya cukup kompetitif, dan lebih mudah didapatkan (Anonim, 2016). Nilai kayu sengon bagi sebagian besar petani memiliki peran penting karena hasilnya mampu memberikan konstribusi finansial dalam menunjang pendapatan keluarga petani (Dwi, 2009). Menurut Widijanto dan Suwarto (2018), penanaman sengon juga berfungsi untuk menerapkan metode konservasi secara vegetatif dalam usaha menekan erosi dan melestarikan sumber daya lahan.

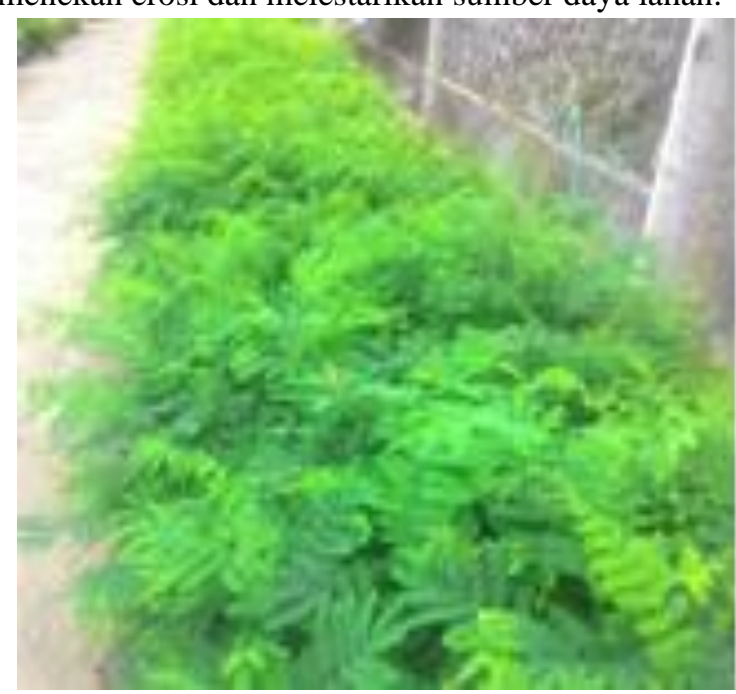

Gambar 11. Bibit Sengon bantuan Balai Pengelolaan Daerah Aliran Sungai dan Hutan Lindung Serayu Opak Progo (BPDASHL SOP)

\subsection{Pembangunan demplot agroforestri}

Dusun Kopeng terletak di lereng Gunung Merapi bagian selatan. Pada wilayah ini, penananaman jenis tanaman kayu-kayuan mempunyai peluang besar karena mampu memberikan manfaat ekonomi serta manfaat konservasi tanah dan air. Hal ini merupakan peluang untuk mengembangkan agroforester dengan jenis sengon di Dusun Kopeng, Desa Kepuharjo, Kecamatan Cangkringan.

Lahan tegalan biasanya ditanami oleh masyarakat dengan pola tumpangsari (campur) untuk mengoptimalkan lahan dan meningkatkan pendapatan finansial. Jenis-jenis tanaman yang ditanam biasanya adalah kombinasi jenis tanaman kehutanan, perkebunan, pertanian, maupun jenis peternakan.
Kombinasi tanaman harus mampu menunjang daya dukung lahan dan tanaman secara berkelanjutan seperti meminimalkan erosi, memulihkan kesuburan tanah, mencegah penguapan yang berlebihan, sebagai tanaman serbaguna, pakan ternak, tanaman pengikat nitrogen, sebagai tanaman pagar hidup, sumber kayu, dan bahan bakar; serta mampu menjadi pengendali gulma, dan penunjang kebutuhan pangan masyarakat sekitar secara berkelanjutan.

Masyarakat Dusun Kopeng sebagian besar sudah paham mengenai sistem agroforestri, tetapi pengoptimalan lahan belum sepenuhnya dilakukan. Sebagian masyarakat hanya menanam jenis-jenis tertentu yang dianggap memiliki nilai jual tinggi sedangkan jenis-jenis yang lain diabaikan tanpa mempertimbangkan kebutuhan pasar di masa yang akan datang. Pelaksanaan penanaman bibit sengon untuk intensifikasi lahan tegalan dengan tujuan untuk meningkatkan pendapatan masyarakat kami laporkan sebagai berikut.

\subsubsection{Pengangkutan}

Bantuan bibit yang diberikan oleh BP DAS HL Serayu Opak Progo (SOP) sebanyak 300 batang. Bibit diangkut dengan mobil bak terbuka dari persemaian menuju ke Dusun Kopeng, Desa Kepuharjo, Kecamatan Cangkringan (Gambar 12).

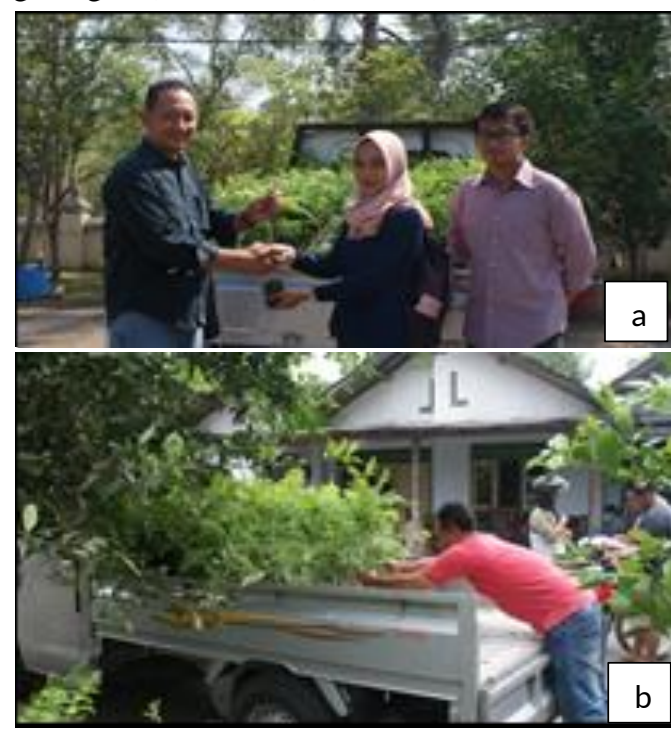

Gambar 12. (a) Pengangkutan bibit dari persemaian dan (b) pembongkaran bibit di halaman rumah Kepala Dusun (Kadus) Kopeng.

\subsubsection{Penanaman}

Kegiatan penanaman diawali dengan pembuatan lubang tanam, kemudian dilanjutkan dengan memasukkan bibit ke dalam lubang tanam. Sebelum ditanam polybag dilepas terlebih dahulu agar pertumbuhan akar tidak terhambat (Gambar 13). 


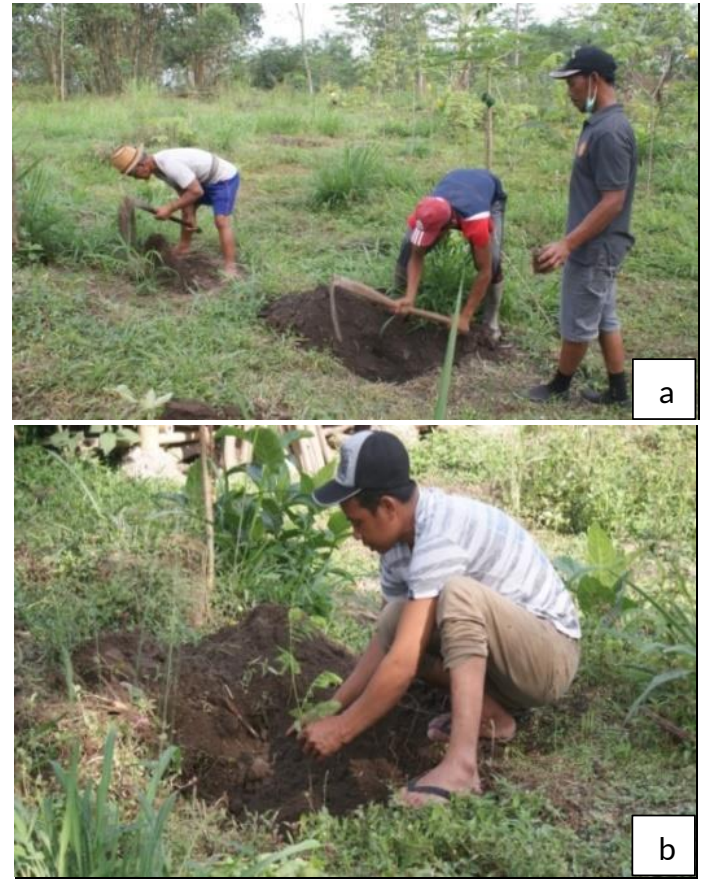

Gambar 13. (a) Pembuatan lubang tanam dan (b) penananam bibit sengon.

Berdasarkan diskusi dengan masyarakat Dusun Kopeng, diketahui bahwa sebagian besar masyarakat menanam berbagai jenis tanaman untuk dibudidayakan, sehingga masyarakat dapat memanen hasilnya secara bergilir. Panen terhadap tanaman semusim, emponempon, dan rumput pakan ternak dapat dilakukan dalam jangka harian, mingguan, dan bulanan. Untuk buah-buahan dan tanaman perkebunan dapat dipanen dalam jangka tahunan, sedangkan tanaman kayu dalam jangka lebih dari 5 tahunan. Penanaman sengon secara agroforestri dapat menjaga kesuburan tanah karena sengon memberikan imbuhan unsur hara nitrogen melalui serasahnya

\section{KESIMPULAN}

Melalui sosialisasi kegiatan diperoleh peningkatan pengetahuan, pemahaman dan kesadaran masyarakat terhadap kondisi lingkungan dan upaya pelestariannya. Selanjutnya melalui perencanaan partisipatif diperoleh informasi jenis tanaman yang diinginkan untuk ditanam oleh petani yaitu sengon (Falcataria moluccana). Sengon memberikan keuntungan ganda, yaitu dalam aspek ekologi dan ekonomi. Peningkatan produktivitas lahan pekarangan dilakukan dengan metode yang ramah lingkungan dalam bentuk intensifikasi pekarangan melalui pola agroforestri. Pengembangan agroforestri dilakukan dengan pembuatan demplot oleh Kelompok Tani Maju Makmur dengan sengon sebagai jenis tanaman yang diusahakan. Pengembangan agroforestri dapat memberikan hasil berupa berbagai jenis tanaman yang dibudidayakan oleh petani dan dapat dipanen secara bergilir. Panen tanaman semusim, empon-empon, dan rumput pakan ternak dapat dilakukan dalam jangka harian, mingguan, dan bulanan. Tanaman buah-buahan dan tanaman perkebunan dapat dipanen dalam jangka tahunan, sedangkan tanaman kayu dalam jangka lebih dari 5 tahunan. Dengan demikian, pendapatan petani akan meningkat. Agar kegiatan penelitian dalam pengabdian kepada masyarakat dapat terlaksana dengan baik, peran dan dukungan berbagai pihak perlu ditingkatkan, baik masyarakat, Fakultas Kehutanan UGM, maupun instansi pemerintah seperti Dinas Kehutanan Provinsi DIY, Balai Pengelolaan DAS Serayu Opak Progo, dan Dinas Kehutanan Kabupaten Sleman. Tahapan kegiatan sebaiknya dilakukan secara partisipasif dan melibatkan pihak-pihak terkait.

\section{UCAPAN TERIMA KASIH}

Penulis mengucapkan terima kasih kepada Fakultas Kehutanan Universitas Gadjah Mada, Herlin Natalia, Nurika Arumsari, Heni Pujiastut, Dinas Kehutanan Provinsi DIY, Balai Pengelolaan DAS Serayu Opak Progo, Dinas Kehutanan Kabupaten Sleman, serta seluruh warga Dusun Kopeng, Desa Kepuharjo, Kecamatan Cangkringan, Kabupaten Sleman yang tergabung dalam Kelompok Tani Maju Makmur atas partisipasi dalam kegiatan pengabdian ini dan bantuan dalam penyediaan lahan dan sarana prasarana yang diperlukan

\section{DAFTAR PUSTAKA}

Arif, N. A. (2020). Modelling the Soil Loss in the Watershed of the Chaddad Wadi in Terms of Both Rockiness and Soil Slaking Indexes. International Journal of Geosciences, 11, 100124. https://www.scirp.org/journal/ijg ISSN Online: 2156-8367. King Khalid University, Abha, KSA.

Hardiatmi, J.M.S. (2010). Investasi Tanaman Kayu Sengon dalam Wanatani Cukup Menjanjikan. INNOFARM: Jurnal Inovasi Pertanian, 9(2), 17-21.

Heru Dwi R., Susi. A, dan Ragil. (2009). Kajian Sengon (Paraserianthes falcataria) Sebagai Pohon Bernilai Ekonomi dan Lingkungan. Jurnal Penelitian Hutan Tanaman, 6(3), 201-208.

Keputusan Presiden Republik Indonesia No. 32 Tahun 1990 tentang Pengelolaan Kawasan Lindung.

Khalif, U., Utami, S.R. dan Kusuma, Z. (2014). Pengaruh Penanaman Sengon (Paraserianthes falcataria) terhadap Kandungan C dan N Tanah di Desa Slamparejo, Jabung, Malang. Jurnal Tanah dan Sumber Daya Lahan, 1(1), 09-15. http://jtsl.ub.ac.id

Kusmawati, W., Zaini, M., dan Ernata, Y. (2018). Pengelolaan Lahan Pekarangan / Kebun dengan Sengon Solomon Hasil Kultur in Vitro pada Kelompok Usaha Pembibitan Sengon di 
Kabupaten Malang. Jurnal Pengabdian Masyarakat, 02(01), 13-20.

Kusumandari, A dan Suryatmojo, H. (2016). Model DAS Mikro sebagai Stratego Pengelolaan Sumber Daya Air secara Partisipatif. Dalam APCE (Asia Pasific for Ecohydrology) Best Learning Pengelolaan Sumber Daya Air. Yogyakarta: Sekolah Pasca Sarjana UGM.

Linsley, R.K., Kohler, M.A., Paulus, J.L.H. (1949). Applied Hydrology. Mac Graw-Hill Company. New York.

Nair, P.K.R. (1993). An Introduction to Agroforestry. Kluwer Academic Publisher. London.

Nugroho, T.A. dan Z. Salamah. (2015). Pengaruh Lama Perendaman dan Konsentrasi Biji Sengon (Paraserianthes falcataria L.). JUPEMASIPBIO, 9(3).

Peraturan Daerah Provinsi Daerah Istimewa Yogyakarta Nomor 2 Tahun 2010 tentang Rencana Tata Ruang Wilayah Provinsi Daerah Istimewa Yogyakarta 2009-2029.
Sari, R.R., Hairiah, K., Suyanto. (2018). Karakteristik Hutan Rakyat Jati dan Sengon Serta Manfaat Ekonominya di Kabupaten Malang. Jurnal Ekonomi Pertanian dan Agribisnis (JEPA), 2(2), 129-137.

Smyle, J., Lobo, C.,Milne, G., dan Williams, M. (2014). Watershed Development in India in Approach Evolving through Experience. AES (Agriculture and Environmental Services) 88056.

Suharti. (2008). Aplikasi Inokulum EM-4 dan Pengaruhnya Terhadap Pertumbuhan Bibit Sengon (Paraserianthes falcataria (L.). Jurnal Penelitian Hutan dan Konservasi Alam, 5(1).

Suprayogi, S., Purnama, Ig. L.S., dan Darmanto, D. (2014). Pengelolaan Daerah Aliran Sungai. UGM Press. Yogyakarta.

Widijanto, H. dan Suwarto. (2019). Penanaman Sengon dalam Gerakan Penghijauan di Desa Sukoharjo, Kecamatan Tirtomoyo, Kabupaten Wonogiri. PRIMA: Journal of Community Empowering and Services, 3(2), 33-37 